\title{
京都市都心部の幹線道路沿いの細街路と高層建築物の関係 \\ A STUDY ON THE RELATIONSHIP BETWEEN HIGH-RISE BUILDINGS AND ALLEYS ALONG ARTERIAL ROADS IN CENTRAL KYOTO CITY
}

\author{
森重幸子 ${ }^{* 3}$, 高田光雄 ${ }^{* 1}$, 前田昌弘 ${ }^{* 2}$, 大森聡子*4 \\ Sachiko MORISHIGE, Mitsuo TAKADA, Masahiro MAEDA \\ and Satoko OMORI
}

\begin{abstract}
The City of Kyoto recently announced a new alley policy, which added the conservation of historical streetscape along alleys as a new policy objective. In the central area of the city, there are high-rise buildings that contrast strongly with lower buildings such as Machiyas along narrow streets. This paper analyzes the sites of the high-rise buildings which face or stand adjacent to alleys. Through this analysis, it clarifies the relationship between high-rise buildings and alleys, and points out the necessity of some regulation for the shape of buildings along alleys in order to conserve the historical streetscape.
\end{abstract}

Keywords : Alleys, High-rise Buildings, Arterial Roads, Machiya 細街路, 高層建築物, 幹線道路, 町家

\section{1.はじめに}

\section{1-1. 研究の背景と目的}

京都市には幅員 $4 \mathrm{~m}$ 未満の道である細街路が約 13000 本存在し、 その総延長は約 $940 \mathrm{Km}$ に及ぶと言われている注1)。細街路は防災上 の危険性が指摘される一方で、歴史的に形成された都市居住の場と して濃密なコミュニティが培われてきたという側面もある。しか し、敷地の狭小性や接道条件による制約から細街路沿いの居住は 不安定な状況におかれている。2011 年 2 月京都市建築審查会より、 細街路対策について、京都の実情に応じた施策の展開を求める建議 が出され、これを受けて 2012 年 7 月、「歴史都市京都における密集 市街地対策等の取組方針」と「京都市細街路対策指針」が発表され た。密集取組方針では、防災安全性を高めつつ歴史都市京都の魅力 である景観やコミュニティを損なわないまちづくりを進めると宣言 している。細街路指針では「歴史細街路」という概念を導入し、歴 史的景観を有している細街路については必ずしも拡幅を前提とせ ず、安全性を確保しつつ良好な景観を維持・継承するための対策を 推進するとしている。すなわち、これまでは拡幅整備と沿道建築物 の更新が細街路対策の主要な政策目標であったのに対して、「京都 らしいまちなみの維持保全」が新たに加えられたと言える。 町家に代表される低層木造家屋が細街路沿いに軒を連ねて高密度
に立ち並ぶ様子は、京都らしいまちなみと考えられる。細街路沿い のまちなみに関する課題としては、個々の建築物の意匠の不統一に よるまちなみの混乱、沿道建築物の更新に伴う敷地後退によって生 じる壁面線のずれ、沿道建築物の管理不全・空き家化によるまちな みの劣化などが挙げられる。さらに、2 階建程度の低層で小規模間 口の建築物によって構成される細街路沿いのまちなみに対して、異 質なボリュームの建築物が混入する際のまちなみの不連続も考えら れる。本研究では、特にこの問題に着目する。

細街路を前面道路とする敷地は、細街路が非道路であれば再建築 不可であり、二項道路であっても道路斜線や容積率規定によって建 築物のボリュームは抑えられる。しかし実際には、複数の接道を 持つなどから細街路沿いの小規模な低層家屋とは大きく異なるボ リュームの建築が細街路に面して建つこともありうる。そこで本研 究は、細街路に面して建てられる高層建築物に対する制御の方法に ついての知見を得ることを目的とし、京都市でも特に容積率が高く 設定され高層の建築物が建築可能な中心部の幹線道路沿いを取り上 げ、細街路と高層建築物の関係の実態を明らかにする。さらに、細 街路沿いのまちなみ一の影響という観点から考察を加えた上で、現 在進められている施策との関わりについて考察する。

\section{1-2. 研究の位置付け}

※本論文は 2014 年住宅系研究報告会論文集に投稿した拙稿「京都市都心部の幹線道路沿いの細街路と高層建築物の関倸」を加筆・修正したものである。

*1 京都大学大学院工学研究科 教授・博士 (工学 $)$

*2 京都大学大学院工学研究科 助教・博士 (工学)

*3 京都大学大学院工学研究科 研究員・修士(工学)

Prof., Graduate School of Eng., KYOTO Univ.,Dr.Eng.

* 4 大阪府 修士 (工学) 
細街路に関する既往研究としては、形成の歴史に関するものや密 集市街地のまちづくり活動に関するものなど幅広いが、本研究との 関わりでは、空間特性や実態を把握するもの ${ }^{4)}$ や、接道不良敷地 に関わる制度や事業の検証を行うもの ${ }^{5 \sim 8)}$ などがある。京都市都 心部の細街路の保全や継承といった観点からの研究の代表的なもの としては、袋路を対象として形成の経緯や実態を把握した上で将来 展望を検討寸るもの ${ }^{9)}$ や接道条件に着目し非道路の実態や行政 による取り扱いの詳細を調查した上で必要な制度要件について検討 するもの ${ }^{10)}$ などがある。いずれも細街路を前面道路とする建築物 と通路を主要な対象としており、本研究は細街路に面して建つ高層 建築物に着目している点が異なっている。細街路と高層建築物の関 係という視点では、細街路が多いことを特徴とする市街地での高層 建築物の開発による問題に着目した研究がある ${ }^{11,12)}$ 。これらは特定 の地区を対象とした地区計画やまちづくりルールを想定したもので ある点で、実態把握の上で現在進められている施策との関わりにつ いて考察する本研究とは異なっている。

\section{1-3. 対象地の概要}

対象として、京都市都心部のいわゆる田の字地区内の幹線道路沿 いの地区を取り上げる。田の字地区は、幹線沿道を中心とする都心 の商業地としての性格と、長く続いてきた職と住とが共存する歴史 的な中心市街地としての性格を併せ持つ地区である。田の字地区の 街区内部は、都心のにぎわいと良好な住環境の調和を目的として、 建物用途の規制や誘導を行う職住共存特別用途地区（以下、「職住 共存地区」と寸る）に指定されている。本研究で着目寸る幹線道路 沿いの地区としては、職住共存地区と周囲の幹線道路に挟まれた地 区を対象とする（以下、「幹線道路沿い」とする）。対象地区はほぼ すべてが商業地域、指定容積率 $700 \%$ 、31m 高度地区に指定されて
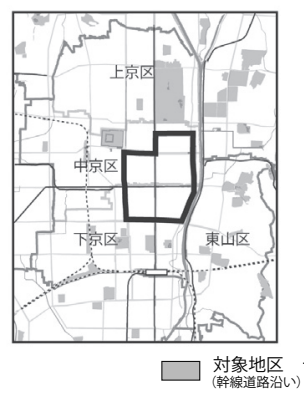
$\Lambda$

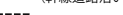

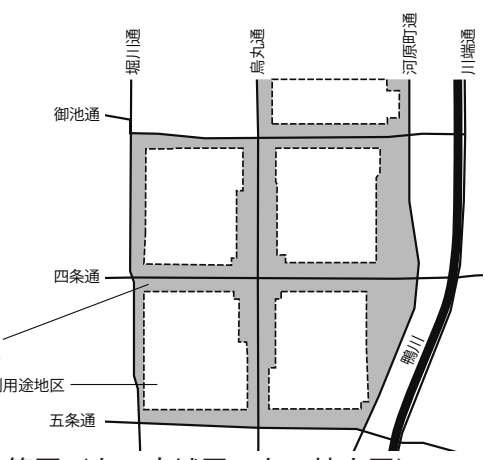

図 1 対象地区の範囲（左：広域図、右: 拡大図）

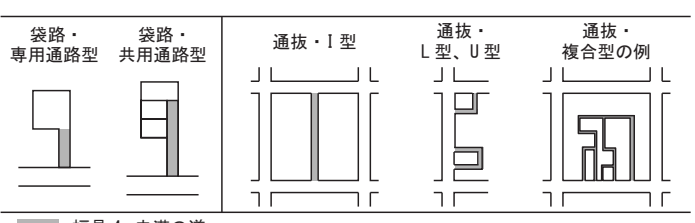

図 2 細街路の類型化

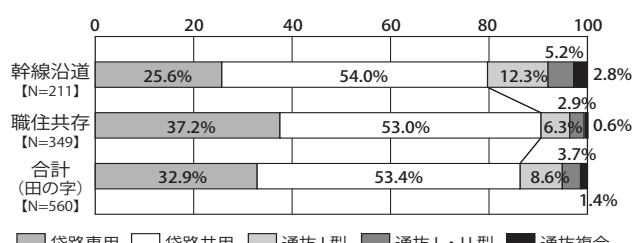

図 3 形態類型別の本数の割合

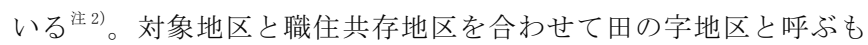
のとする。

\section{2. 田の字地区内の細街路の類型化と傾向}

田の字地区内の細街路について、平成 18 年度に行われた京都市 都心部の細街路の悉皆調查注3) のデータをもとに位置を把握し、住 宅地図および現地調查により現存するかどうかと形状の確認を行っ た。現地調查は 2013 年 9 月に行った。その結果、幹線道路沿いに は 211 本、職住共存地区には 349 本、田の字地区合計では 560 本の 細街路が存在した。幹線道路沿いと職住共存地区の境界線をまたぐ ように存在する細街路は幹線道路沿いとして計上した。

細街路は、行き止まりになっている袋路と、一般道路に通り抜け ることができる通り抜けの 2 種に大別できる。さらに、袋路は接続 する敷地の数によって専用通路型と共用通路型が存在した。通り抜 けは、幅員 $4 \mathrm{~m}$ 以上の一般道路によって囲まれる街区の一方から反 対側へと通り抜けるI 型、同じく正方形街区の一方からその直行方 向の外周道路へと通り抜けるL型、および、折れ曲がって同じ道路 へと戻るU型が見られた。さらに、I 型、L型、U型のいずれにも 分類できない、複数の経路が存在する通り抜けは複合型に分類した (図 2 )。通り抜けに接続する袋路状部分は袋路として計上した。

袋路と通り抜けの本数の割合を見ると、田の字地区では全体の $86 \%$ が袋路だった。幹線道路沿いと職住共存地区を比較すると、職 住共存地区のほうが袋路の割合が高く、90\%が袋路だった。平成 18 年調查の都心 4 区（上京・中京・下京・東山）では袋路が $62 \%$ 、 平成 24 年の細街路対策指針では市内都市計画区域全域では袋路が $33 \%$ となっているのに比べて、田の字地区は特に袋路の割合が高い と言える。

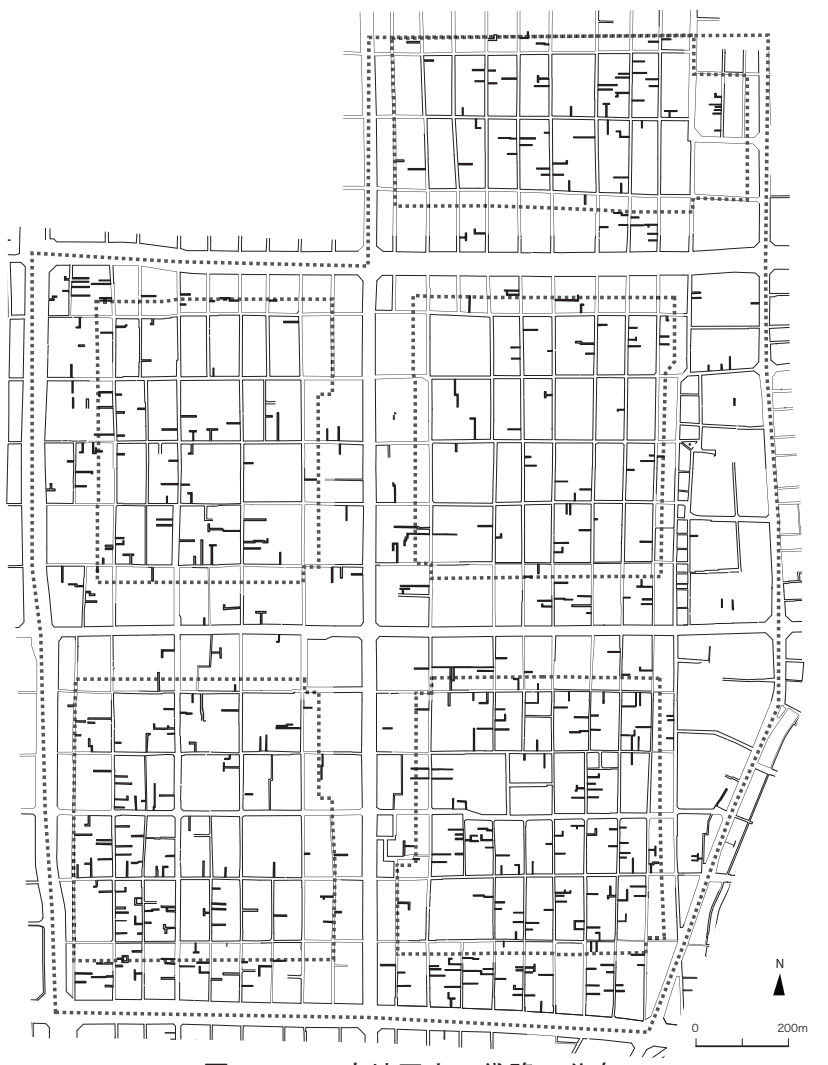

図 4 田の字地区内の袋路の分布 


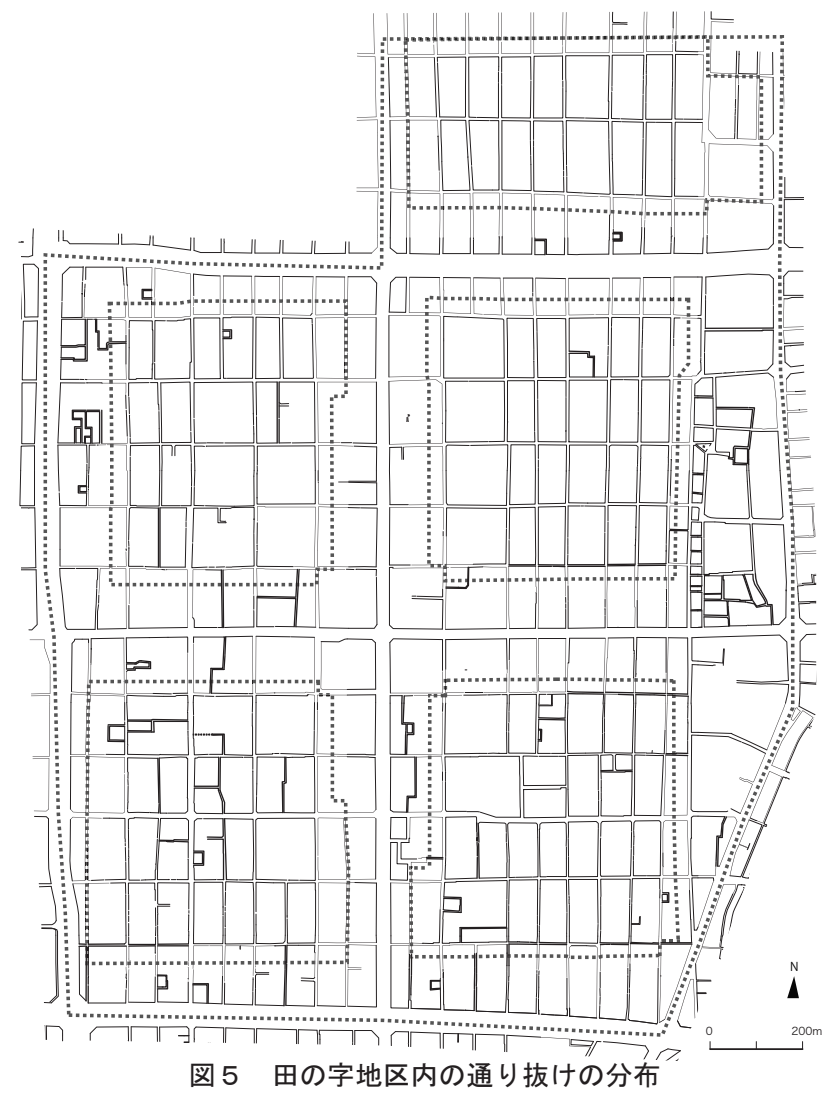

形態類型別の本数の割合をみると、幹線道路沿い、職住共存地区 ともに、最も多かったのは袋路共用型で、全体の本数の $50 \%$ 強を 占めていた。また、職住共存地区では袋路専用型の割合が $37 \%$ にっ ていたのに対し、幹線道路沿いでは $25 \%$ とやや低くなっており、そ の分幹線道路沿いでは通り抜けの割合が高くなっていた。通り抜け の本数は全体的に少ないが、その中では I 型が多く、L型、U 型、 複合型は少数である(図 3 )。

図 4、図 5 に、田の字地区内の袋路と通り抜けの分布図を示す。 袋路は基盤目状になった街区の内側へと伸びる比較的延長距離の短 い小規模なものが多い。対象地区内で見られたU型通り抜けは、通 り抜けではあるものの比較的近い距離で同じ道に戻ってくることか ら、通過利用は想定しにくいという意味で、袋路に近い性質を持っ ていると言うことができる。

\section{3. 細街路と高層建築物の敷地の関係の分析}

\section{3-1. 細街路に面する高層建築物}

幹線道路沿いで細街路に高層建築物の敷地が面している事例を全 て抽出した。2 階建程度を中心とする細街路沿いの低層のまちなみ に対して突出する高さとして、高さ $15 \mathrm{~m}$ を超える建築物を高層建築 物と定義した。対象地区である幹線道路沿い地区の高さ規制は $31 \mathrm{~m}$ であり、隣接する職住共存地区は高さ規制 $15 \mathrm{~m}$ となっている。ま た、「敷地が面する」とは敷地境界線が細街路の通路部分の外形線 に接している状態を指し、建築物自体の配置や形態は問わないもの とする。住宅地図および現地調查により高さ $15 \mathrm{~m}$ 超と思われる建築 物の敷地が細街路に面する事例を抽出した上で、建築計画概要書に より建築物の高さを確認した。その結果、該当する高層建築物の数 は 68 件（建設中含む）であった注4)。これらの高層建築物の敷地が

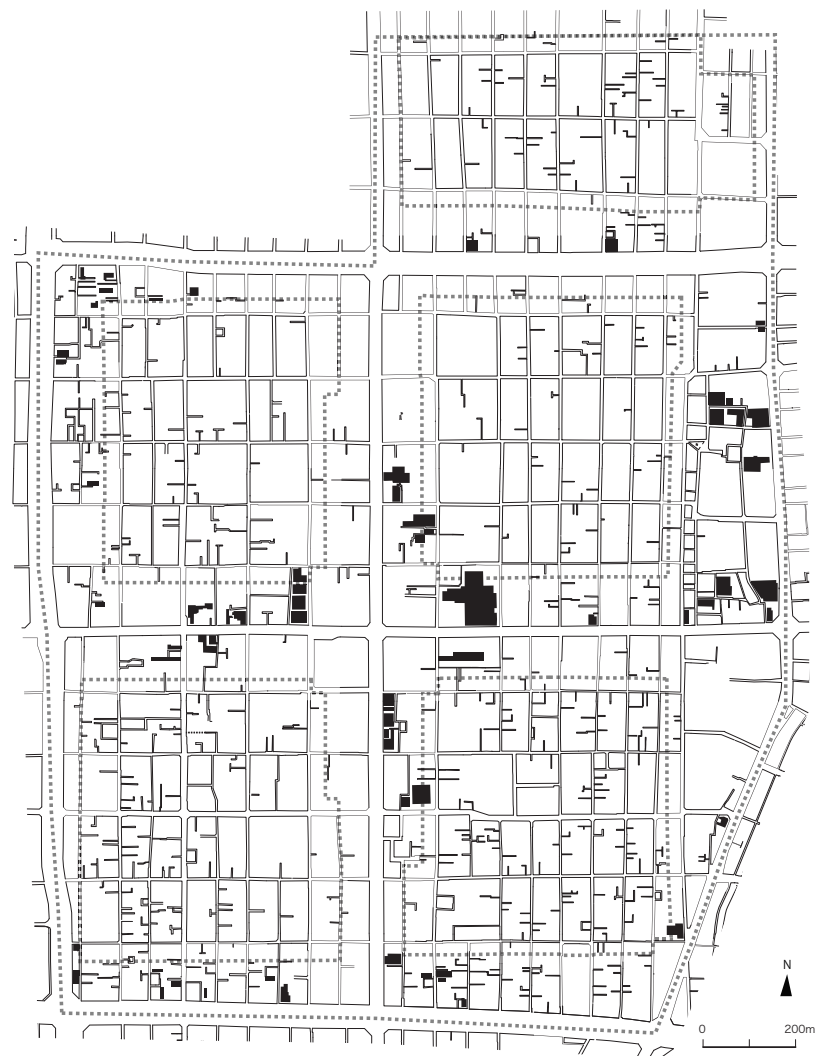

図 6 幹線道路沿いの細街路に面する高層建築物の分布

表 1 高層建築物が面する細街路の本数と割合

\begin{tabular}{|c|c|c|c|c|}
\hline & $\begin{array}{c}\text { 対象地区内の } \\
\text { 細街路数 } \\
(\text { 本) }\end{array}$ & $\begin{array}{l}\text { 高層建築物の } \\
\text { 地が面する } \\
\text { 細街路 }\end{array}$ & 割合 & $\begin{array}{c}\text { 面する } \\
\text { 高層建築物の } \\
\text { 敷地数 (件) }\end{array}$ \\
\hline 袋路 & 168 & 23 & $13.1 \%$ & 30 \\
\hline 専用通路型 & 54 & 3 & $5.6 \%$ & 3 \\
\hline 共用通路型 & 114 & 20 & $17.5 \%$ & 27 \\
\hline 通抜 & 43 & 22 & $51.1 \%$ & 42 \\
\hline I 型 & 26 & 11 & $42.3 \%$ & 17 \\
\hline L型 & 5 & 3 & $60.0 \%$ & 7 \\
\hline U型 & 6 & 3 & $50.0 \%$ & 4 \\
\hline 複合型 & 6 & 5 & $83.3 \%$ & 14 \\
\hline 合計 & 211 & 45 & $21.3 \%$ & $72 \%$ \\
\hline
\end{tabular}

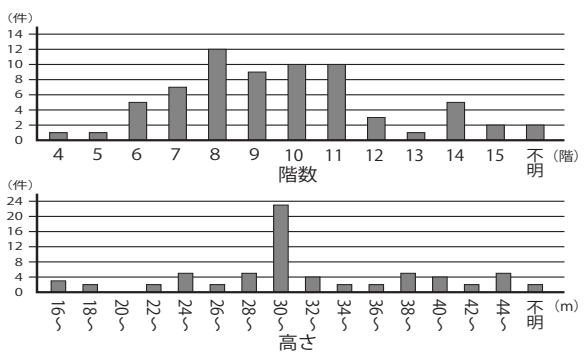

図 7 細街路に面する高層建築物の階数と高さ

面する細街路は袋路が 23 本、通り抜けが 22 本、合計 45 本だった。 対象地区内の袋路と通り抜けの本数に対する割合を見ると、袋路は 全体の $13 \%$ 程度であるのに対し、通り抜けは約半数と高い割合で高 層建築物が存在している。

高層建築物の主要用途で最も多かったのは共同住宅 35 件で、続 いて商業施設 13 件、事務所 12 件、宿泊施設 6 件、その他 2 件だっ た。階数は $8 \sim 11$ 階建程度を中心に 4 階建から 15 階建まで分散し 
ている一方で、高さは $31 \mathrm{~m}$ 制限ぎりぎりである $30 \mathrm{~m}$ 程度に集中し ている。この地区は 2007 年に高さ制限が $31 \mathrm{~m}$ に引き下げられたが、 以前の $45 \mathrm{~m}$ 制限時に建てられた $31 \mathrm{~m}$ 超の建築物も 26 件あった。

\section{3-2. 細街路に面する高層建築物の敷地の分類}

図 8 は、細街路に面する高層建築物の敷地を、細街路の通路部分、 細街路沿いの敷地との関係性、および前面道路から分類したもので ある。他のパターンも考えられるが、対象地区内に実在したパター ンのみを記している。袋路に面する事例は合計で 30 件、通り抜け に面する事例は 42 件あった。高層建築物は 68 棟であるが、うち 4 棟が 2 本の細街路に面しており、各細街路に対する関係性によって 事例の分類を行ったため、事例数の合計は 72 件になっている。袋 路に面する事例は全て袋路以外の一般道路を前面道路としており、 通り抜けに面するもののうち 2 件のみ、通り抜け細街路を前面道路 としていた。

\section{3-3. 高層建築物の敷地が袋路に面するパターン}

23 本の袋路中 7 本の袋路には 2 件の高層建築物の敷地が面して おり、袋路に面寸る高層建築物の事例数は 30 件だった。袋路と高

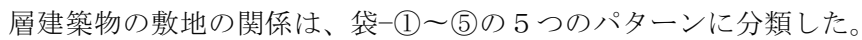

袋一(1) は、袋路の始端部から袋路の通路部分に高層建築物の敷地 が接するパターンであり、袋路に接続する奥の敷地が袋路の通路を 挟んで高層建築物の敷地と反対側に位置するものである。袋-(2)も、 始端部から袋路の通路部分に高層建築物の敷地が接するパターンで あるが、袋-1)とは異なり、袋路に接続する奥の敷地が高層建築物 と同じ側に位置するものである。

袋-(3)は、袋路の通路部分の一部に高層建築物の敷地が接してい るが、袋路の始端部と高層建築物の敷地は接していないパターンで ある。袋-(4)は袋-(3)と類似したパターンであるが、袋-(3)は高層建 築物の敷地の前面道路と袋路が接続する一般道路が同じであるのに 対して、袋-(4)の高層建築物の敷地は、街区の直行方向の道路また
は街区の反対側の道路を前面道路としている点で異なっている。

袋一(5)は、以前は袋路に接続する奥の敷地のうちの一区画であっ たと推定できる土地が、隣接する別敷地と一体化されたことによ り、高層建築物の建つ敷地が袋路の通路部分に接するようになった ものである。

最も多く見られたのは袋-(1)のパターンで、14 件が該当した。14 件中 3 件が袋路・専用通路型に面しており、残り 11 件は共用通路 型に面していた。田の字地区内の袋路は全般的に小規模なものが多 く、11 件の共用通路型の袋路も全体的に延長距離の短いものが多 かった。接続する敷地の数でみると、9 件が敷地数 4 以下の短い袋 路になっており、残りの 2 件は、敷地数 7 と敷地数 11 であり少し 長い袋路だった。他のパターンは袋-(1)に比べて少なく、袋-(2)は 3 件、袋-(3)は 6 件、袋-(4)は 5 件、袋-(5)は 2 件だった。

袋-(5)は他の袋路のパターンとは異なり、袋路沿いの敷地の一区 画を高層建築物の敷地として取り込んでいる。これに該当する事例 は 2 件あり、いずれも袋路側に $2 \mathrm{~m}$ 程度の視線の通らない塀を立て、 出入口は無く、完全に塞がれている状態だった。うち 1 件は内部を 自転車置き場として利用していたが、もう 1 件は共同住宅である高 層建築物の利用者も入ることの無い空き地になっていた。建築計画 概要書によると、建ぺい率規制 80\% のところ $79.62 \%$ で建築されて おり、袋路沿いの一区画を取り込むことによって敷地面積を拡大 し、建築面積を最大化する狙いがあったとみられる。

\section{3-4. 高層建築物の敷地が通り抜けに面するパターン}

22 本の通り抜けに 42 件の高層建築物の敷地が面しており、袋路 に比べて、1 本の細街路に面する高層建築物の数が全体として多く、 面する敷地数の最大は 5 件だった。通り抜けと高層建築物の敷地の 関係は、以下の 7 つのパターンに分類した。

通-(1)および通-(2)は、U型通り抜けに高層建築物の敷地が接する パターンである。通-(1) は、高層建築物の敷地がU型通り抜けの一

\section{表 2 対象地区内で細街路に敷地が面する高層建築物}

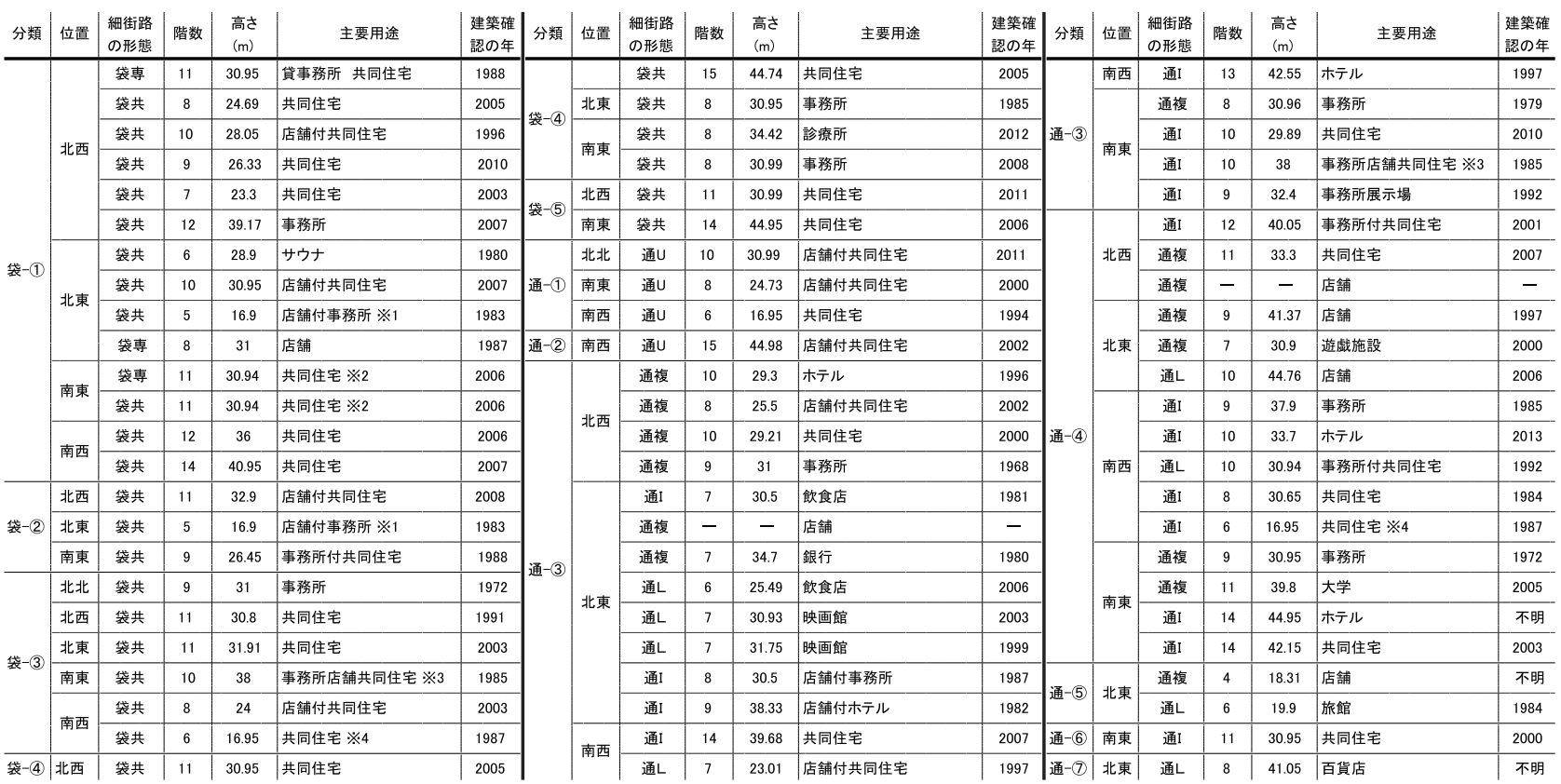

注）位置：田の字地区内の 5 つの街区の位置を示す。北北：御池通以北、北東：四条通以北烏丸通以東、北西：四条通以北烏丸通以西、南東：四条通以南烏丸通以東、南西：四条通以南烏丸以西 ※: 高層建築物の重複を示す。数字が同じものが同一の高層建築物。 


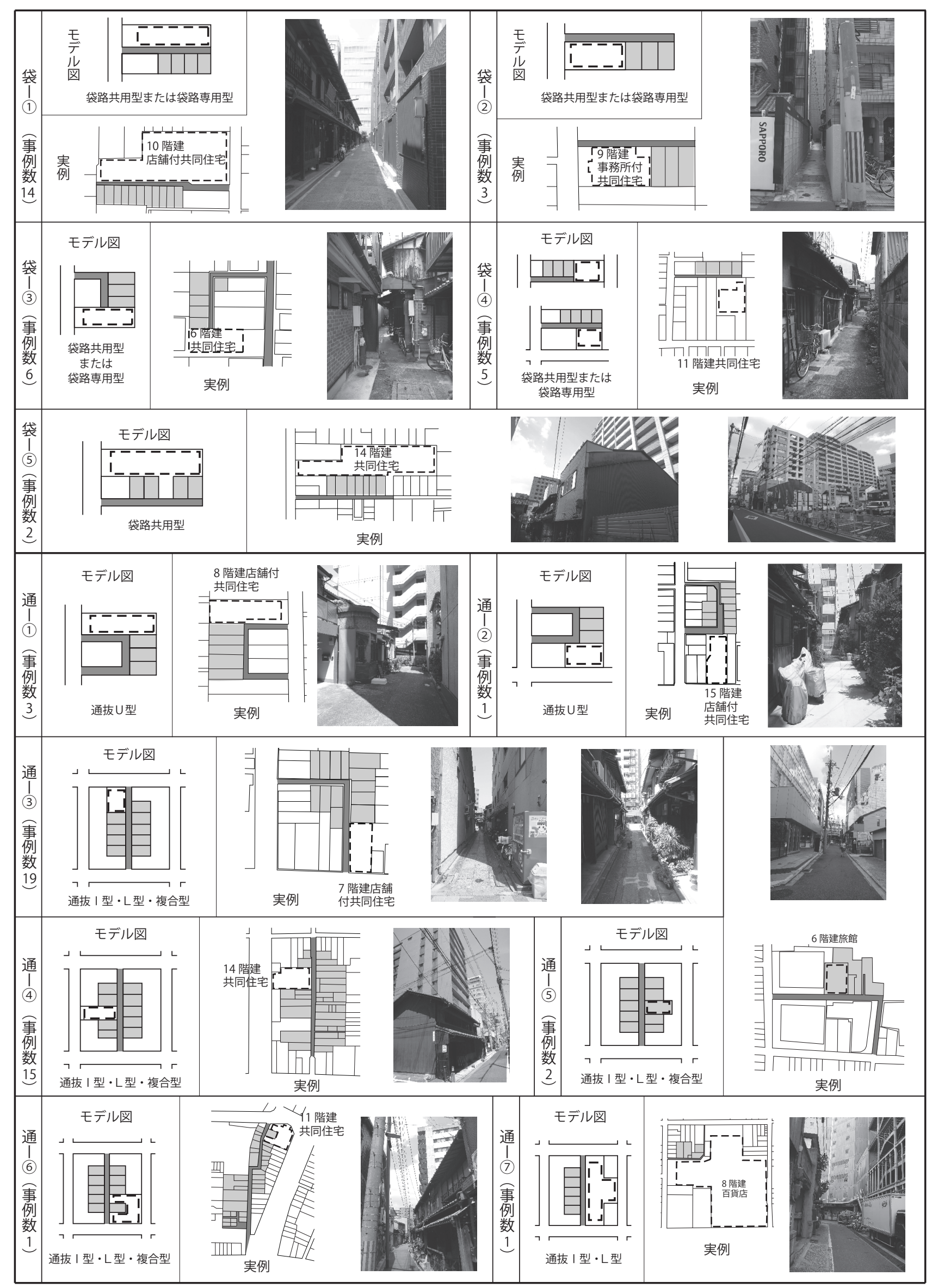

凡例 $\square$ 細街路 $\square$ 細街路にのみ面する敷地 I

※実例の図の方位は全て上を北とする

図 8 細街路に面する高層建築物の敷地の分類 


\section{表 3 細街路に面する高層建築物の敷地のパターンの整理}

\begin{tabular}{|c|c|c|c|c|c|}
\hline $\begin{array}{l}\text { パタ } \\
\text { ーン }\end{array}$ & $\begin{array}{c}\text { 敷地が面 } \\
\text { する細街路 } \\
\text { の形状 }\end{array}$ & $\begin{array}{c}\text { 細街路の } \\
\text { 始端部敷地に } \\
\text { 該当するか※1 }\end{array}$ & $\begin{array}{l}\text { 細街路沿いの } \\
\text { 立ち敷地 } \\
\text { を含むか※2 }\end{array}$ & $\begin{array}{c}\text { 細街路が接続する } \\
\text { 一般道路と高層 } \\
\text { 建築物の敷地の } \\
\text { 前面道路の関係 }\end{array}$ & $\begin{array}{l}\text { 該当 } \\
\text { 例数 }\end{array}$ \\
\hline 袋-(1) & \multirow{5}{*}{ 袋路 } & $\begin{array}{l}\text { 該当する(立ち並ひ教地 } \\
\text { と前面道路の間を遮らない) }\end{array}$ & 含まない & 同じ & 14 \\
\hline 袋-(2) & & $\begin{array}{l}\text { 該当する(立ち並び粨地 } \\
\text { と前面道路の間を遮る) }\end{array}$ & 含まない & 同じ & 3 \\
\hline 袋-(3) & & 該当しない & 含まない & 同じ & 6 \\
\hline 袋-4) & & 該当しない & 含まない & 異なる & 5 \\
\hline 袋-(5) & & 該当しない & 含む & 同じ & 2 \\
\hline 通-(1) & \multirow{2}{*}{ 通抜U型 } & 該当する & 含まない & 同じ & 3 \\
\hline 通-(2) & & 該当しない & 含まない & 異なる & 1 \\
\hline 通-(3) & \multirow{5}{*}{$\begin{array}{l}\text { 通抜 L 型 } \\
\text { ｜＼cjkstart型・ } \\
\text { 複合型 }\end{array}$} & 該当する & 含まない & 同じ & 19 \\
\hline 通-(4) & & 該当しない & 含む & 異なる & 15 \\
\hline 通-(5) & & 該当しない & 含む & $\begin{array}{c}\text { 細街路を前面道路とする } \\
\text { (般道路に面さない) }\end{array}$ & 2 \\
\hline 通-(6) & & 該当する & 含む & 同じ道と異なる道共に面する & 1 \\
\hline 通-(7) & & 該当する & 含む & 同し道と異なる道共に面する & 1 \\
\hline
\end{tabular}

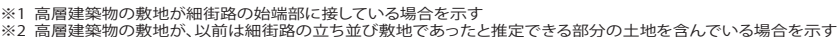
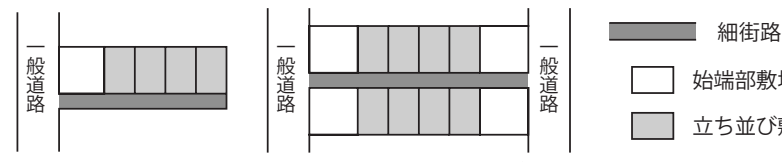

$\square$ 始端部敷地

立ち並び敷地

図 9 始端部敷地と立ち並び敷地の概念

方の始端部に接しているのに対して、通-(2)は始端部には接してい ない点が異なっている。

通-(3)は、通り抜けの始端部に接して高層建築物の敷地があるパ ターンであり、通-(4)は通り抜けの始端部ではなく途中部分に接し て高層建築物の敷地があるパターンである。通-(5)は通-(4)と同様、 通り抜けの途中に高層建築物の敷地が接しているが、通-(4)が他の 一般道路にも接道しているのに対して、通一(5)は他に接道を持たな い点で異なっている。

通-(6)、高層建築物の敷地が通り抜けの始端部に接し、通り抜 け沿いの小規模な別の区画を挟んで再度通り抜けに接するというパ ターン、通-(7)は通り抜けの片側全てを大規模な高層建築物の敷地 が占めるというパターンで、それぞれ 1 事例のみが該当した特殊な 事例であると言える。

最も多く見られたのは通-(3)のパターンで 19 件が該当、続いて通 -(4)が 15 件該当し、他のパターンはいずれも少数だった。通-(3) 細街路が一般道路に接続する角地に位置するもので、一般道路に囲 まれた街区の外周で更新と高層化が進んでいる状況を表していると 考えられる。

\section{4. まちなみの視点と政策との関連性}

\section{4-1. 高層建築物の敷地のパターンの整理}

分類した高層建築物の敷地のパターンは、細街路の始端部敷地・ 立ち並び敷地との関係、および細街路の接続する一般道路と敷地の 前面道路との関係から表 3 のように整理することができる。

細街路の始端部敷地とは、細街路が一般道路に接続する部分の角 地に当たる土地を呼ぶものとする。細街路の入り口として緊急時に も重要な位置であり、後述する政策的な視点にも関わりがある。

立ち並び敷地とは、細街路を前面道路として接続する土地を呼ぶ ものとする（図 9)。細街路を通ってアクセスされていた土地とも 言い換えることができる。細街路沿いのまちなみは、立ち並び敷地 に小規模低層の建物が複数連続して並ぶことによって形成されると
捉えることができる注5)

袋路は、通路部分の片側だけに立ち並び敷地がある場合と両側に 立ち並び敷地がある場合が考えられるが、今回の対象地区内で高層 建築物の敷地が面した袋路はいずれも片側のみに立ち並び敷地があ る袋路だった。そのため、立ち並び敷地の一区画を取り込んだパター ンである袋-(5)以外の 4 つのパターンは、立ち並び敷地を含まない としている。通り抜けについては、始端部以外で通り抜け通路に接 している場合を、立ち並び敷地を含むと判定した。通-(4)、通-(6)、 立ち並び敷地部分の土地を別の土地と一体化した土地を敷地として 高層建築物が建設された様子が読みとれる。通-(5)、立ち並び敷 地そのものが高層建築物の敷地になっており 2 件が該当した。通一 (7)は 1 事例のみが該当した例で、周辺の敷地よりも極端に大きな敷 地が L型通り抜けの片側を占めていることから、立ち並び敷地を含 む複数の土地が一体化して現状に至っていると判断している。

細街路が接続する一般道路と高層建築物の敷地の前面道路の関係 は、「異なる」または「同じ道と異なる道ともに面する」場合に、 高層建築物の敷地が、細街路沿いの立ち並び敷地とは異なるコミュ ニティに所属する可能性を意味する。

\section{4-2. 細街路沿いのまちなみの視点}

\section{4-2-1. 袋路沿いのまちなみの視点}

細街路沿いのまちなみという観点からみると、まず、立ち並び敷 地に小規模低層建築物が複数並んでいる中に、高層建築物がそれら の低層建築物に並ぶように立つ場合に、まちなみへの影響が大きく なると考えられる。

高層建築物の敷地が袋路の立ち並び敷地を含むパターンとしては 袋-(5)が該当する。袋-(5)の 2 件は前述のように、取り込んだ立ち並 び敷地をオープンスペースとして利用しており、2 事例とも袋路側 に閉鎖的な塀が立てられていたが、袋路側の境界のしつらえがまち なみに影響するといえる。また、対象地区内では見られなかったが、 袋路沿いの立ち並び敷地を複数取り込むなどによりある程度の面積 が確保されれば、袋路に面した部分に高層建築物が建つことも考え られる。その場合、現時点では基本的に袋路は非道路であるため注6) 道路斜線規定がかかることもなく、隣地斜線規定の範囲内で注7) 袋 路に面して高層建築物の建築が可能であり、袋路沿いに低層の建築 物が立ち並ぶ場合、まちなみへの影響は大きい。

袋一(1) は、立ち並び敷地を含むわけではないが、高層建築物が袋 路の通路空間を挟んで袋路沿いの立ち並び敷地と向かい合うパター ンであり、該当する事例数も多い。該当する事例では、袋路全体の 奥行きとほぼ同程度の奥行きをもつ隣接する敷地に高層建築物が 立っている例が多く見られた。これは、袋路が元はひとつの敷地だっ たところの奥に家を建てて道を引き込み形成されたことによると推 測できる。袋路は基本的に非道路であるため、高層建築物の敷地か らみると袋路側との境界線は隣地境界線扱いである。隣地間のまち なみの不連続という点では、従来から京都市都心部のまちなみ景観 の問題とされてきた、町家に隣接して高層建築物が建つ状況と類似 した状況であると言える。ただし、共用通路型の袋路である場合そ の通路は袋路居住者にとっては道であること、特に立ち並び敷地の 数が多く連続したまちなみを形成している場合もあることなどが異 なっている。

\section{4-2-2. 通り抜け沿いのまちなみの視点}




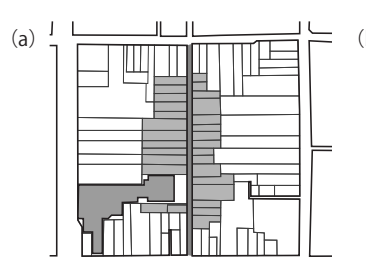

$$
\neg
$$

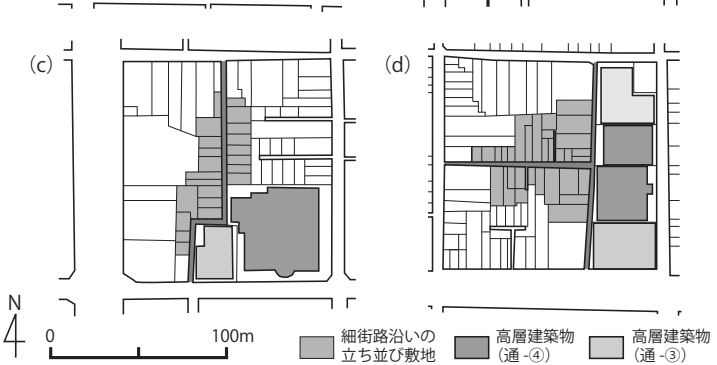

図 10 通一(4)に該当する事例

高層建築物の敷地が、通り抜け沿いの立ち並び敷地を含むパター ンとしては、通-(4)、(5)、(6)、(7)が該当する。その中でも通-(4)は 15 件と比較的多くの事例が該当している。対象地区内の通り抜け は概补袋路よりも延長距離が長く、立ち並び敷地によるまちなみも 形成されや寸い状況にある。また、立ち並び敷地の関係者のみの利 用が想定される、私的な性質が強いと考えられる袋路やU型通り抜 けよりも、通り抜けできる形状であり道としての公共的性質も相対 的に高いと考えられる。これらのことから、通-(4)はまちなみへの 影響に最も注意が必要なパターンであると言うことができる。

通-(4)に該当する事例を見ると、図 10 の (a) のように、細街路沿 いに高層建築物が 1 件のみあるもの、(b)、(c) のように複数ある もの、さらに (d) のように細街路の片側に完全に高層建築物だけが 並んでいるものもあった。対象としている田の字地区は近代化以前 から市街化している歴史的市街地であり、現存する細街路沿いには 二項道路指定の基準時には既に建築物の立ち並びがあったと考えて よいため、通り抜けは基本的に二項道路であると考えられる。道路 斜線の存在から壁面後退も誘導されやすい状況にあるが、細街路沿 いに壁面線の揃った低層のまちなみが存在する場合は、壁面後退に よるまちなみの分断も生じる。

さらに、このような高層建築物は、一般道路側に主要なエントラ ンスを設けることで、細街路側には裏側としてのしつらえをするこ とになり、建築物自体のボリュームによるまちなみの分断に加え て、意匠的な面からもまちなみへの影響が危惧される。

またこのパターンの敷地は、通り抜け沿いの敷地のいわゆる背割 線をまたいで一般道路まで繋げた敷地形状となっている。京都市中 心部のコミュニティは通りを挟んだ両側町を基本的な構成単位とす るが、このような敷地はその単位を逸脱したものであり、既存のコ ミュニティへの影響も懸念される。通一(4)、および事例数は少ない が通-(6)や通-(7)は、通り抜け細街路側のコミュニティと外周道路側 のコミュニティの両方に関わる敷地の形状となっており、既存のコ ミュニティの境界線を壊すものとなっている。

通-(5)は唯一細街路を前面道路とするパターンであり 2 件が該当 した。いずれも $45 \mathrm{~m}$ 制限時の建築であったが高さは $18.3 \mathrm{~m} 、 19.9 \mathrm{~m}$ となっており、今回抽出した 62 件の中では比較的低い。細街路を 前面道路として $15 \mathrm{~m}$ 超の建築物が建つのは、細街路が二項道路の場
合である注9)。他に接道を持たないこのパターンでは、壁面後退に

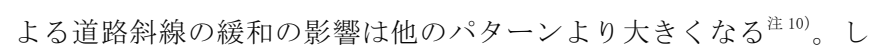
かし大きく壁面後退するにはある程度の敷地規模を必要とするた め、小規模な立ち並び敷地が連続しているような場合は、単独の立 ち並び敷地では起こりにくいと考えられる。今回該当した 2 件はい ずれも細街路沿いにある程度の規模の商業建築が並ぶ立地であり、 立ち並び敷地における小規模敷地の連続も見られなくなっている街 区であった。

通-(6)、(7)は、対象地区内で各 1 事例見られたが、特殊なパター ンと考えられる。始端部敷地と立ち並び敷地の両方を敷地に含んで おり、通一(3)通-(4)の両方の性質を持つと考えられる。

\section{4-3. 現在進められている施策との関連 \\ 4-3-1. 細街路対策指針で示された考え方}

平成 24 年に発表された細街路対策指針では、基本的な考え方々 して、「ア細街路における避難安全性の向上」、「イ細街路における 建築物の更新」「ウ細街路における京都らしさの維持・再生」の 3 点を挙げている。「細街路における京都らしさ」の内容として「町 並夕」と「コミュニティ」の 2 点が言及されている。

3 点目のウについては、前節の検討より、通-(4)、袋 - (5)、(1)が特に、 細街路沿いのまちなみに与える影響について注意すべきパターンで あると言える。

アの避難安全性については、特に袋路における緊急時の避難経路 の確保が求められる。今回の分類では、袋-(2)以外のパターンの場 合に高層建築物の敷地側に非常用の避難口を設置することが考えら れるが、対象地区内の事例には見られなかった。京都市は平成 24 年 7 月に袋路奥から避難経路をつくる工事費の助成事業を開始して おり、このような事例に対して避難経路確保を積極的に誘導するこ とが考えられる。

イの建築物の更新については、細街路沿いの建築物の老朽化を防 ぎ耐震性と防火性を高めることを目標としており、その観点から みると細街路沿いに建つ高層建築物は基本的に望ましいものと言 える。袋路始端部敷地の建築物の安全性は特に重視されており注8)、 表 3 で「始端部敷地に該当する」となっているパターンはこれに該 当する。非道路扱いとなっている袋路では、始端部敷地に高層建築 物が建つ場合、袋路側に敷地後退の義務が生じないため、袋路の幅 員は既存のまま拡幅されない。特に、袋一(2)のように袋路沿いの立 ち並び敷地と表の一般道路との間を高層建築物が塞ぐように建つこ とは、現状の袋路幅員および敷地割を固定化する方向に働く。そう であれば、単に防火性・耐震性の高い建築物を建てることが望まし いという単純な評価はできない。

\section{4-3-2. 新しい道路指定基準と細街路条例}

細街路対策指針に従い、平成 26 年 4 月に非道路（袋路および $1.8 \mathrm{~m}$ 未満の細街路）を道路指定する際の基準と手続きが明確化され、道 路指定された道路にのみ接する敷地における建築物への制限を定め る条例が施行された注11)。これは、前述のイ建築物の更新という目 的を実現するための方策と考えられ、非道路を道路化することによ り、接道不良敷地を接道させ、建築行為を可能とするものである。 非道路が二項道路または三項道路に指定された場合、建築物の規模 や用途、構造に制限が課される。二項道路の場合は 3 階建以下、三 項道路の場合は 2 階建以下が求められることから、まちなみとして 
は低層のまちなみが継続すると考えられる。しかしこのような制限 は当該道路のみに接道寸る敷地に対寸る制限であり、今回実際の例 として多く見られたような、他に道路で接道条件を満たしている敷 地に対しては適用されない。

\section{5. 結論}

以上、本研究では、まず京都市都心部の幹線道路沿いに位置する 細街路に面する高層建築物の敷地を取り上げ、細街路との関係性の 全てのパターンを整理し、実態を明らかにした。

通り抜けと袋路を比較すると通り抜けに高い割合で高層建築物の 敷地が面しており、対象地区内の通り抜けの約半数で該当する事例 が見られた。ほとんど全ての事例が細街路ではなく別の一般道路を 前面道路として計画されており、細街路を前面道路とする事例は 2 件だった。細街路を前面道路とする場合は容積率制限と道路斜線制 限によって規模が抑えられるものの、道路斜線緩和と壁面後退によ るまちなみへの影響は問題である。

事例数が多く見られたパターンとしては、通り抜けの始端部敷地 に高層建築物の敷地が位置するもの（通-(3)・19 件）、通り抜けの 途中に高層建築物の敷地が接するもの（通-(4)・15 件)、袋路の通 路に隣に高層建築物の敷地が位置するもの（袋-11)・14件）が挙げ られる。

細街路沿いのまちなみに与える影響という観点からは、比較的延 長距離が長く立ち並び敷地によるまちなみが形成されやすいこと、 それらの立ち並び敷地に並んで高層建築物の敷地が入ること、また 袋路より道としての公共性が高いことから、通-(4)のパターンが最 も細街路沿いのまちなみへの影響が大きいと考えられる。またこの パターンはコミュニティとの関係にも課題があることを指摘してい る。

現在進められている施策は、非道路の道路化によって沿道建築物 の更新を可能とするものであり、その際には建築物は低層に制限さ れるが、通一(4)のような別に接道をもつ高層建築物には適用されな い。この施策の目的は沿道建築物の安全性の向上が主眼であり、ま ちなみの維持保全という目的はまだ具体的な施策に反映されていな いと考えられる。高層建築物は細街路沿いのまちなみを不可逆的に 変質させるものである。現状では、2 以上の前面道路をもつ道路斜 線制限の緩和やその他の緩和規定が複雑に存在しており 注 12$)$ 、結果 的に細街路側にあらわれる建築物の形態によって、不連続なまちな みが誘導されている状況にある。細街路沿いのまちなみの維持保全 には、高さと壁面の位置といった点についての細街路側からの形態 規制が求められる。

\section{謝辞}

本研究は 2013 年度大学コンソーシアム京都未来の京都創造研究事 業および 2013 年度公益財団法人 LIXIL 住生活財団の助成を受けて 行った研究成果に基づくものです。記して謝意を表します。

注

注 1 ）市内都市計画区域全域の細街路。「細街路対策指針」より。

注 2 ）北街区の一部に、容積率 $600 \% 20 \mathrm{~m}$ 第 4 種高度地区、近隣商業地域・容 積率 $300 \% 15$ m 第 3 種・第 4 種高度地区、を含む。
注 3 ) 平成 18 年度に京都市および大津市の細街路を対象として行われた「京 都を中心とした歷史都市の総合的魅力向上調查に係る 歴史都市の美しい細 街路の維持・保全のための調查」。結果は文献 1 で報告されている。

注 4 ）建築計画概要書が無い建築物が 2 件あったが、目視により明らかに高さ 15m 超であったため件数に含めている。

注 5 ) 各細街路に対する立ち並び敷地の範囲を正確に把握するには厳密には各 細街路が形成された時期の地図に遡る必要があるが、本研究では現状の敷地 割りおよび近年の住宅地図から推定している。

注 6 ）京都市は二項道路を指定する告示において、「ただし袋路は除く」と規 定している。平成 26 年 4 月施行の新しい道路指定基準によって、一定の条 件を満たし、権利関係者の合意によって申請された袋路については二項道路 指定することも可能になった。

注 7) 対象地区の道路斜線規制は $1: 1.5$ 、隣地斜線制限は立ち上がり $31 \mathrm{~m}+1: 1.5$ である。高度地区による絶対高さ制限が $31 \mathrm{~m}$ であるため、隣地斜 線制限は実質的に無い状態である。

注 8 ）袋路始端部の建物の耐震・防火改修を促進するため、平成 24 年 7 月よ り「袋路始端部における耐震・防火改修助成事業」によって工事費の $100 \%$ 上限 150 万円の助成が行われている。

注 9 ）非道路においても 43 条但し書き許可または連担建築物設計制度を利用 すれば建替えは可能であるが、3 階建までに制限されている。

注 10）一般道路を前面道路としている通一(5)以外の通り抜けに接するパターン では、 2 以上の前面道路がある場合の道路斜線制限の緩和が一定の適用距離 内で利用できることから、通り抜け細街路側からの道路斜線制限による影響 は通-(5)より小さくなる。

注 11）「京都市道路の指定等に関する基準」および「京都市細街路にのみ接す る建築物の制限等に関する条例」

注 12) 建築基準法第 56 条第 7 項による特例 (天空率) による高さ制限の緩和や、 建築基準法第 52 条第 9 項(特定道路への接続)による容積率制限の緩和など。

\section{参考文献}

1）国土交通省住宅局、京都市・大津市・宇治市三都市協議会 : 京都を中心と した歷史都市の総合的魅力向上調査に係る歴史都市の美しい細街路の維持・ 保全のための調查研究報告書、2007.3

2) 京都市 : 歴史都市京都に㧍ける密集市街地対策等の取組方針、2012.7

3) 京都市: 京都市細街路対策指針、2012.7

4) 原田陽子：大阪市空堀地区における路地単位特性と接道不良長屋所有者の 居住改善実態一木造密集市街地における地域資源を活かした住環境の保全 的更新関寸る研究一、日本建築学会計画系論文集、第 669 号、pp. 21172126、2011.11

5 ）山崎明子・中林一樹：東京区部における地域特性と細街路整備諸施策のあ り方に関する研究 (1)一 23 区の細街路整備に関する経年比較と地域間比較の 視点から一、日本建築学会計画系論文集、第 663 号、pp. 947-956、2011.5

6 ) 有田智一・岩田司: 接道困難敷地の実態に対応した接道特例許可の運用の あり方一中野区のケース・スタディー、日本建築学会計画系論文集、第 533 号、pp. 135-142、2000.7

7 ）金贵錫・高見沢実 : 密集市街地整備のための連担建築物設計制度の運用に 関する研究一京都市、神戸市、荒川区の地域別特性を中心にして一、日本都 市計画学会都市計画論文集、No. 40-1 pp. 91-96、2005

$8 ） 川$ 川崎興太：路地保全を前提とした木造密集市街地における居住環境整備方 策に関する研究一東京都中央区月島地区における 3 項道路型地区計画の初動 的な実績と効果一、日本都市計画学会都市計画論文集、No. 41-3 pp. 10131018、2006

9 ）上林研二：路地型共同住宅の改善と継承的再開発に関する研究、京都大学 博士学位論文、1996

10）三森弘：接道規定からみた京都・都心部の路地空間の特徵及び維持・保全 に関する研究、筑波大学博士学位論文、2013

11）松井大輔・寉田亜矢 : 神楽坂花街における町並み景観の変容と計画的課題、 日本建築学会計画系論文集、第 680 号、pp. 2407-2414、2012.10

12）中須啓介、野沢千絵: 神楽坂地区における地区計画に基づく建て替えによ る路地空間の変化分析、日本建築学会大会学術講演梗概集 F-1 (都市計画)、 pp. 63-64、2008. 9 


\title{
A STUDY ON THE RELATIONSHIP BETWEEN HIGH-RISE BUILDINGS AND ALLEYS ALONG ARTERIAL ROADS IN CENTRAL KYOTO CITY
}

\author{
Sachiko MORISHIGE ${ }^{* 3}$, Mitsuo TAKADA ${ }^{* 1}$, Masahiro MAEDA *2 \\ and Satoko OMORI*4 \\ ${ }^{* 1}$ Prof., Graduate School of Eng., KYOTO Univ.,Dr.Eng. \\ ${ }^{* 2}$ Assistant Prof.,Graduate School of Eng., KYOTO Univ.,Dr.Eng. \\ ${ }^{* 3}$ Reseach Fellow,Graduate School of Eng., KYOTO Univ.,M.Eng. \\ ${ }^{*}$ Osaka Prefecture, M.Eng.
}

The City of Kyoto recently announced a new alley policy, which added the conservation of historical streetscape along alleys as a new policy objective. On those sites which face narrow streets, to build high-rise buildings is basically restricted by Building Standard Law because of the narrow width of its front road, although there are high-rise buildings along narrow streets in the central area that contrast strongly with other lower buildings such as Machiyas. High-rise buildings along alleys can exert enormous influence to historical landscape.

The purpose of this paper is to point out the actual situations of the relationship between high-rise buildings and alleys in the central area of Kyoto city in order to bring out some knowledge on the way of conservation of historical streetscape along alleys.

First, this paper shows the general representation of the alleys situated in the central area of the city, so-called Tanoji area. We did the complete enumeration about the alleys in this area. There are 560 alleys in this are. Alleys can be divided broadly into two categories, one is blind alleys and the other is walk-through alleys. Blind alleys are classified by number of the connecting site, singly site blind alleys and multi sites blind alleys. Walk-though alleys are classified by the shape of the alley, I shape type, U shape type, L shape type, and composition type. 86\% of the all alleys in Tanoji area is blind alleys, to the contrast to the proportion of Kyoto City in which blind alleys account for only $33 \%$. The most popular type in Tanoji area is multi sites blind alleys, which account for more than half of the all alleys in this area.

Next, we examined high-rise buildings of which sites face alleys alongside arterial roads of Tanoji area. Alongside arterial roads, the height regulation is 31 meters, while that of the rest of the Tanoji area is 15 meters. Therefore we define that High-rise buildings mean over 15 meters height in this paper. The number of the high-rise building concerned is 68 , which contains 35 condominiums, 13 commercial architectures, 12 office buildings, 6 accommodations, and 2 others. The number of alleys concerned is 45,23 is blind alleys and rest 22 is walk-through alleys. It can be said that walk-through alleys are major by ratio.

We broke those high-rise building sites into patterns from the viewpoint of the relationship between the site and alleys. For blind alleys we found 5 patterns, for walk-through alleys 7 patters. Major patterns are blind alley pattern 1, walk-through pattern 3, and walk-through pattern 4. Blind alley pattern 1 is that the site of high-rise building locates just next to the blind alley way space. The number of this case is 14 . In this pattern, lower buildings and high-rise building face off against across narrow blind alley. Walk-through pattern 3 is that the site of high-rise building locates just the entrance corner of the walk-through alley. The number of this case is 19. Walk-through pattern 4 is that the site of high-rise building locates middle part of the walk-through alley. The number of this case is 15 . High-rise buildings of this pattern affect most to the streetscape along alleys.

Through this analysis, it clarifies the relationship between high-rise buildings and alleys, and points out the necessity of some regulation for the shape of buildings along alleys in order to conserve the historical streetscape. 